\title{
INKOMPATIBILITAS ABO PADA NEONATUS DI UTD PMI KOTA BANDA ACEH TAHUN 2018
}

\author{
Teuku Ilhami Surya Akbar ${ }^{1}$, Ni Ken Ritchie ${ }^{2}$, Nurmala Sari ${ }^{3}$ \\ ${ }^{1}$ Fakultas Kedokteran, Universitas Malikulsaleh,dan UTD PMI Kota Banda Aceh \\ ${ }^{2}$ Fakultas Kedokteran, Universitas Indonesia, Jakarta, dan UTD PMI DKI Jakarta \\ ${ }^{3}$ Unit Transfusi Darah PMI Kota Banda Aceh.
}

Corresponding author : teukuilhamisuryakbar.85@gmail.com

\begin{abstract}
Abstrak
Inkompatibilitas $\mathrm{ABO}$ atau ketidak cocokan golongan darah $\mathrm{ABO}$ pada neonatus merupakan salah satu penyebab ikterik patologis atau hiperbilirubinemia. Inkompatibilitas golongan darah ABO umumnya penyakit yang tidak berat, namun perlu penanganan sebaikbaiknya karena jika tidak dapat berdapak buruk bayi neonatus. Inkomptabilitas ABO terjadi pada $12 \%$ kehamilan, tetapi hanya $2 \%$ yang berkaitan dengan hemolisis berat. Ibu biasanya memiliki golongan darah $\mathrm{O}$ dan janin memiliki golongan darah $\mathrm{A}, \mathrm{B}$ atau $\mathrm{AB}$. Penelitian ini melihat prevalensi $\mathrm{ABO}$ inkompatibilitas pada neonatus dan penanganan yang dilakukan di UTD PMI Kota Banda Aceh. Tujuan penelitian ini untuk mengetahui presentase inkompatibilitas ABO di UTD PMI Kota Banda Aceh dan juga penanganan yang selama ini dilakukan. Metoda penelitian ini menggunakan desain deskriptif dengan pendekatan cross sectional dan pengambilan data menggunakan data sekunder. Total sampel berjumlah 4.500 kasus. Hasil penelitian menunjukkan presentase Inkompatibilitas ABO pada neonatus sebesar $0,5 \%$ dan diberikan penanganan berupa fototerapi dan transfusi darah. Kesimpulannya 1/20 neonatus yang diperiksakan darahnya di UTD PMI Kota Banda Aceh mengalami inkompatibilitas $\mathrm{ABO}$, diharapkan ibu hamil dapat mengetahui golongan darahnya sebelum persalinan dan melakukan pemeriksaan terkait resiko inkompatibilitas.
\end{abstract}

Kata kunci: Inkompatibilitas ABO; neonatus; fototerapi; transfusi darah. 


\title{
ABO INCOMPATIBILITY IN NEONATES AT UTD PMI BANDA ACEH CITY IN 2018
}

\begin{abstract}
$\mathrm{ABO}$ incompatibility or $\mathrm{ABO}$ blood group incompatibility in neonates is one of the causes of pathological jaundice or hyperbilirubinemia. ABO blood group incompatibility is generally a non-severe disease, but it needs to be handled as well as possible because if it can not have bad neonatal babies. ABO incompatibility occurs in $12 \%$ of pregnancies, but only $2 \%$ are associated with severe hemolysis. Mothers usually have blood type $\mathrm{O}$ and the fetus has blood type A, B or AB. This study looked at the prevalence of ABO incompatibility in neonates and the treatment carried out at UTD PMI Banda Aceh City. The purpose of this study was to determine the percentage of ABO incompatibility in the UTD PMI Banda Aceh City and also the handling that has been done so far. This research method uses descriptive design with cross sectional approach and data collection using secondary data. The total sample was 4,500 cases. The results showed that the percentage of $\mathrm{ABO}$ incompatibility in neonates was $0.5 \%$ and treatment was given in the form of phototherapy and blood transfusion. In conclusion, 1/20 neonates whose blood was examined at UTD PMI in Banda Aceh experienced ABO incompatibility, it is expected that pregnant women can find out their blood type before delivery and do an examination related to the risk of incompatibility
\end{abstract}

Keywords: ABO incompatibility; neonates; phototherapy; blood transfusion

Jurnal Averrous Vol.5 No.2 November 2019

Page 59-75 


\section{PENDAHULUAN}

Di Indonesia, bayi dengan ikterus masih merupakan masalah terutama pada bayi yang kurang bulan dengan presentase lebih dari $25-50 \%$ dibanding dengan neonatus yang cukup bulan. ${ }^{1}$ Ikterus pada neonatus dapat bersifat fisiologis dan pada patologis, yang ditandai dengan hiperbilirubinemia dan jika tidak ditangani dengan cepat dapat menimbulkan gangguan yang menetap atau menyebabkan kematian sehingga setiap bayi dengan ikterus harus mendapatkan perhatian, terutama pada ikterus patologis atau hiperbilirubinemia yang ditemukan dalam 24 jam pertama kehidupan bayi atau kadar bilirubin meningkat $>5 \mathrm{mg} / \mathrm{dL}$ $(>86 \mu \mathrm{mol} / \mathrm{L})$ dalam 24 jam. $^{2}$

Inkompatibilitas $\mathrm{ABO}$ atau ketidak cocokan golongan darah $\mathrm{ABO}$ pada neonates merupakan salah satu penyebab ikterik patologis atau hiperbilirubinemia. Inkompatibilitas golongan darah ABO umumnya penyakit yang tidak berat, namun perlu penanganan sebaikbaiknya. Inkomptabilitas ABO terjadi pada 12\% kehamilan, tetapi hanya 2\% yang berkaitan dengan hemolisis berat. ${ }^{3}$ Ibu biasanya memiliki golongan darah $\mathrm{O}$ dan janin memiliki golongan darah $\mathrm{A}, \mathrm{B}$ atau $\mathrm{AB} .^{4}$

Kondisi ini terjadi pada saat darah ibu dan bayi yang berbeda golongan darahnya bercampur dan mengakibatkan inkompatibel, dimana darah ibu dan bayi yang bercampur akan membentuk zat anti dari serum darah ibu, sehingga imunitas ibu akan menganggap eritrosit bayi sebagai antigen dalam kandungan. Sehingga tidak jarang embrio hilang pada sangat awal secara misterius, sebelum ibu menyadari bahwa ia hamil, namun apabila janin yang dilahirkan hidup, maka dapat terjadi ikterus yang dapat mengarah pada ikterus patologis atau hiperbilirubinemia. Apabila hal ini tidak ditangani secara tepat dapat menimbulkan kematian atau kelainan perkembangannya seperti gangguan perkembangaan mental, tuli, lambat bicara dan lain-lain. ${ }^{5}$ Inkompatibilitas golongan darah ABO lebih sering ditemukan di Indonesia dibanding inkompatibilitas golongan darah lainnya. ${ }^{6}$ Menurut statistik kira-kira $20 \%$ dari seluruh kehamilan terlibat dalam ketidakcocokan golongan darah $\mathrm{ABO}$ dan $75 \%$ dari jumlah ini terdiri dari ibu golongan darah $\mathrm{O}$ dan janin golongan darah $\mathrm{A}$ atau B. ${ }^{7}$

Survey pendahuluan yang dilakukan di Rumah Sakit Nirmala Suri Sukoharjo menyebutkan jumlah persalinan pada tahun 2008 sampai 2010 sebanyak 1687 persalinan, dimana untuk angka kejadian ikterus sebanyak 84 baik ikterus fisiologis maupun ikterus 
patologis untuk yang diakibatkan karena inkompatibilitas ABO yang juga memegang peranan penting dalam terjadinya hiperbilirubinemia angka kejadiannya tidak dihitung dengan pasti. ${ }^{8}$

Pemahaman, penanganan dan edukasi yang baik terkait kasus inkompatibilitas $A B O$ ini sangat penting guna mencegah kompilikasi yang dapat ditimbulkan dari kasus ini terutama pada neonatus pada ibu, keluarga dan tenaga medis.

\section{METODE}

Penelitian ini menggunakan desain deskriptif dengan pendekatan cross sectional dan pengambilan data menggunakan data sekunder dengan pendekatan retrospektif. Data diambil dari UTD PMI Kota Banda Aceh pada periode 2018, dengan melakukan perbandingan jumlah sampel darah yang dilakukan cross matching dengan jumlah sampel darah yang inkompatibel. Penentuan inkompatibilitas dilakukan melalui pemeriksaan cross matching (uji silang serasi) dilakukan dengan metode gel tes (BIORAD). Cross matching merupakan persyaratan mutlak darah dapat dikeluarkan atau tidak sesuai dengan PERMENKES No 91 tahun 2015. Prinsip cross mathing ada tiga :

1. Mayor cross matching, merupakan uji kecocokan dengan melihat ada tidaknya reaksi antara serum pasien dan sel donor.

2. Minor cross matching, merupakan uji kecocokan dengan melihat ada tidaknya reaksi antara serum donor dan sel pasien.

3. Autokontrol cross matching, merupakan uji kecocokan dengan melihat ada tidaknya reaksi antara serum pasien dan sel pasien.

Prosedur Pemeriksaan Crossmatch (Pre Analitik, Analitik dan Post Analitik)

\section{Metode : gel test (aglutinasi)}

Prinsip: antibodi yang terdapat dalam serum/plasma, bila direaksikan dengan antigen pada sel darah merah, dan diinkubasi pada suhu $30^{\circ} \mathrm{C}$ selama 15 menitdan dengan penambahan anti monoglobulin akan terjdi reaksi aglutinasi.

Tujuan: Untuk mendeteksi kecocokan darah pasien dan darah donor.

\section{Alat dan Bahan}

- Mikropipet

- Gunting

- Rak tabung

- Sentrifuge 
- Incubator

- Tabung reaksi

- Saline

- Gel test

\section{Prosedur :}

1. Membuat suspensi sel pasien dan donor:

- Memasukan 0,5 ml Dil/saline kedalam tabung

- Ambil $5 \mu 1$ PRC atau WB, massukan kedalam tabung.

- Campur dan homogenkan suspensi.

\section{Ambil liss/Coombs Card}

- Mayor: $50 \mu 1$ Suspensi Sel Donor $+25 \mu 1$ serum pasien

- Minor : $50 \mu 1$ suspensi sel pasien $+25 \mu 1$ serum donor

- Autokontrol: $50 \mu 1$ suspensi sel pasien $+25 \mu 1$ serum pasien.

- Homogenkan dengan menggunakan jari

- Memasukan kedalam inkubator $37^{\circ} \mathrm{C}$ selama 15 menit.

- Memasukan kedalam sentrifuge, selama 10 menit

- Baca reaksi aglutinasi yang terdapat dalam sampel.

\section{Pemeriksaan DCT (direct coombs test)}

- Membuat suspensi sel pasien

- Ambil liss/coombs card, tandai dengan identitas pasien

- Masukan $50 \mu 1$ suspensi sel pasien

- Masukan kedalam sentrifuge

- Baca reaksi yang terjadi.

Interpretasi Hasil :

\begin{tabular}{|l|l|l|l|l|}
\hline No & Mayor & Minor & AC/DCT & Kesimpulan \\
\hline 1 & - & - & - & Darah keluar \\
\hline 2 & + & - & - & Ganti darah donor/Rujuk \\
\hline 3 & - & + & - & \\
\hline 4 & - & + & + & $\begin{array}{l}\text { Beri PRC bila minor lebih kecil } \\
\text { atau sama dengan AC/DCT }\end{array}$ \\
\hline 5 & + & + & + & Darah tidak dapat keluar \\
\hline
\end{tabular}

\section{Keterangan :}


1. Crossmatch Mayor, Minor, Dan Ac $=$ Negatif

- Darah pasien cocok dengan darah donor

- Darah dapat diberikan kepada pasien

2. Crossmatch Mayor $=$ Positif, Minor $=$ Negatif, $\mathrm{AC}=$ Negatif

Periksa kembali golongan darah Os dan donor

- Kemudian periksa DCT pada donor bila hasil positif maka darah donor tersebut harus disingkirkan karena akan selalu positif pada crossmatch mayor.

- Apabila golongan darah sudah sama dan DCT donor negatif maka kemungkinan ada antibodi irreguler pada darah OS.

- Ganti darah donor lakukan crossmacth lagi sampai didapat hasil crossmatch negatif.

- Apabila tidak ditemukan hasil cossmatch yang compatible meskipun darah donor telah diganti maka harus dilakukan screening dan identifikasi antibodi pada serum OS, dalam hal ini sampel darah dikirim ke UTD pembina terdekat.

3. Crossmatch Mayor $=$ Negatif, Minor $=$ Positif, $A c=$ Negatif

- Terdapat antibodi irreguler pada serum atau plasma donor

- Solusinya berikan PRC atau ganti dengan darah donor lain, bila yang diperlukan adalah plasma, trombosit, WB kemudian lakukan crossmatch lagi.

4. Crossmatch Mayor $=$ Negatif, Minor $=$ Positif, $\mathrm{AC}=$ Positif

- Dilakukan combs test pada OS

- Apabila DCT = Positif, hasil positif pada crossmacth minor dan AC berasal dari autoantibodi.

- Apabila derajat positif pada minor sama atau lebih kecil dibandingan derajat positif pada AC atau DCT, berikan PRC.

- Apabila derajat positif pada minor lebih besar dibandingkan derajat positif pada AC atau DCT, darah tidak boleh dikeluarkan. Ganti darah donor, lakukan crossmatch lagi sampai ditemukan positif pada minor sama atau lebih kecil dibandin AC atau DCT.

5. Crossmatch Mayor, Minor, dan $\mathrm{AC}=$ Positif.

- Periksa ulang golongan darah OS maupun Donor baik dengan cell grouphing maupun back typing, pastikan tidak ada kesalahan golongan darah.

- Positif pada minor kemungkinan berasal dari autoantibodi pada OS.

- Sedangakan positif pada mayor dapat disebabkan oleh irreguler antibodi pada serum OS. 
- Jika memungkinkan lanjutkan pemeriksaan dengan screening dan identifikasi antibodi.

Data disajikan dalam bentuk presentase hasil pemeriksaan inkompatibel dengan jumlah pemeriksaan sampel yang diperiksa.

\section{HASIL PENELITIAN}

Presentase Inkompatibilitas ABO pada neonatus $0,5 \%$ atau $1 / 20$ neonatus yang diperiksakan darahnya di UTD PMI Kota Banda Aceh mengalami inkompatibilitas.

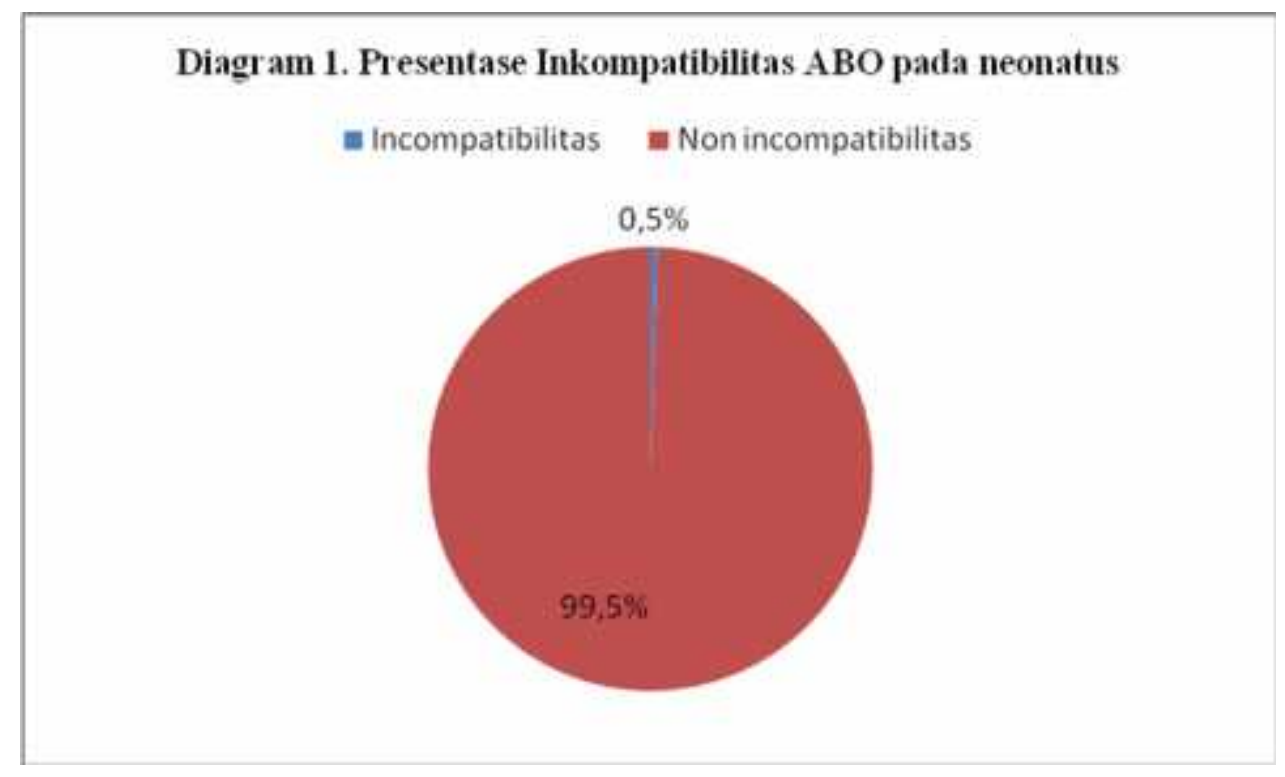

Diagram 1. Presentase Inkompatibilitas ABO pada Neonatus.

\section{DISKUSI}

Secara umum, ketidak sesuain atau inkompatibilitas dalam konteks golongan darah ini disebabkan oleh pengikatan antibodi plasma dengan antigen sel darah merah, sehingga menyebabkan reaksi. Ketidak sesuaian ini dapat berakibat fatal jika diberikan kepada pasien,sesuai dengan Permenkes no. 91 tahun 2015,dimana setiap darah yang akan dikeluarkan atau diberikan kepada pasien harus memiliki nilai yang kompatibel atau sesuai. ${ }^{9}$

Pada penelitian ini menunjukkan presentase Inkompatibilitas pada kasus ABO pada neonatus $0,5 \%$ atau $1 / 20$ neonatus yang diperiksakan darahnya di UTD PMI Kota Banda Aceh mengalami inkompatibilitas, hal ini ditandai dengan tes laboratorium dimana reaksi inkompatibilitas akan divisualisasikan dengan aglutinasi dari sel-sel darah merah. Di tubuh, reaksi antigen-antibodi dapat terjadi sebagai konsekuensi yang merugikan dari transfusi darah Jurnal Averrous Vol.5 No.2 November 2019 
atau kehamilan, mengakibatkan kerusakan sel darah merah dipercepat. Oleh karena itu penting untuk mendeteksi ketidaksesuaian antara plasma pasien dan sel darah merah dari donor darah potensial sebelum transfusi, untuk menghindari reaksi transfusi. Ketidakcocokan terjadi pada kehamilan saat ibu diimunisasi oleh immunoglobulin (Ig) janin yang melewati plasenta. ${ }^{10}$ Inkompatibilitas dapat dibedakan menjadi dua yaitu inkompatibilitas ABO dan inkompatibilitas Rhesus. Inkompatibilitas ABO adalah kondisi medis dimana golongan darah antara ibu dan bayi berbeda sewaktu masa kehamilan. Terdapat 4 jenis golongan darah, yaitu A, B, AB dan O. Golongan darah ditentukan melaluitipe molekul (antigen) pada permukaan sel darah merah. Sebagai contoh, individu dengan golongan darah A memiliki antigen A, dan golongan darah $\mathrm{B}$ memilki antigen $\mathrm{B}$, golongan darah $\mathrm{AB}$ memiliki baik antigen $\mathrm{A}$ dan $\mathrm{B}$ sedangkan golongan darah $\mathrm{O}$ tidak memiliki antigen. ${ }^{11}$

Golongan darah yang berbeda menghasilkan antibodi yang berbeda-beda. Ketika golongan darah yang berbeda tercampur, suatu respon kekebalan tubuh terjadi dan antibodi terbentuk untuk menyerang antigen asing di dalam darah. Inkompatibilitas ABO seringkali terjadi pada ibu dengan golongan darah $\mathrm{O}$ dan bayi dengan golongan darah baik $\mathrm{A}$ atau $\mathrm{B}$. Ibu dengan golongan darah $\mathrm{O}$ menghasilkan antibodi anti-A dan anti-B yang cukup kecil untuk memasuki sirkulasi tubuh bayi, menghancurkan sel darah merah janin.

Penghancuran sel darah merah menyebabkan peningkatan produksi bilirubin, yang merupakan produk sisa. Apabila terlalu banyak bilirubin yang dihasilkan, akan menyebabkan ikterus pada bayi. Bayi dengan ikterus akan memerlukan fototerapi atau transfusi ganti untuk kasus berat. Apabila bayi tidak ditangani, bayi akan menderita cerebral palsy. Sampai saat ini, tidak ada pencegahan yang dapat memperkirakan inkompatibilitas ABO. Tidak seperti inkompatibilitas $\mathrm{Rh}$, inkompatibilitas $\mathrm{ABO}$ dapat terjadi pada kehamilan pertama dan gejalanya tidak memburuk pada kehamilan berikutnya. ${ }^{5}$

Sedangkan, inkompatibilitas $\mathrm{Rh}$ adalah suatu kondisi yang terjadi ketika seorang wanita hamil memilikidarah Rh-negatif dan bayi dalam rahimnya memiliki darah Rh-positif. Selama kehamilan, sel darah merah dari bayi yang belum lahir dapat menyeberang ke aliran darah ibu melalui plasenta. Jika ibu memiliki Rh-negatif, sistem kekebalan tubuhnya memperlakukan sel-sel $\mathrm{Rh}$ positif janin seolah-olah mereka adalah substansi asing dan membuat antibody terhadap sel-sel darah janin. Antibodi anti-Rh ini dapat menyeberang kembali melalui plasenta ke bayi yang sedang berkembang dan menghancurkan sel-sel darah merah bayi. 
Sel-sel darah merah yang dipecah menghasilkan bilirubin. Hal ini menyebabkan bayi menjadi kuning (ikterus). Tingkat bilirubin dalam aliran darah bayi bisa berkisar dari ringan sampai sangat tinggi. Karena butuh waktu bagi ibu untuk mengembangkan antibodi, bayi sulung jarang yang mengalami kondisi ini, kecuali ibu mengalami keguguran di masa lalu atau aborsi yang membuat peka sistem kekebalan tubuhnya. Namun, semua anak-anaknya telah setelah itu yang memiliki Rh-positif dapat terpengaruh. ${ }^{12}$

\section{Penyebab Inkompatibilitas}

\section{Secara Umum}

Penyebab Reaksi Hemolitik Fatal karena ABO Transfusi Darah yang Tidak Kompatibel ${ }^{10}$

1.1. Adanya kesalahan identifikasi (nursing error)

Pada kasus ini pasien mendapatkan darah yang keliru oleh karena perawat tidak mencocokkan label pada darah dengan identitas pasien pada gelang yang digunakan oleh pasien, selain itu menanyakan ke pasien apakah nama pasien benar atau tidak, dimana seharusnya tidak boleh dilakukan, jadi seharusnya biarkan pasien yang menyebutkan namanya sendiri .

\subsection{Label sample darah tertukar (phlebotomist error)}

Terjadi akibat banyaknya pasien yang memerlukan komponen darah sehingga tidak menutup kemungkinan label sample darah tertukar. Akibatnya adalah pasien mendapatkan sample darah keliru dan dampak yang ditimbulkan juga sangat fatal.

\subsection{Adanya kesalahan saat mengambil sample (phlebotomist error)}

Darah yang diambil oleh petugas kesehatan adalah darah orang lain sehingga akan menimbulkan dampak yang fatal. Contoh kasus di klinik adalah petugas kesehatan mengambil darah penunggu pasien akibat penunggu pasien tidur di bangsal dan petugas kesehatan tidak menanyakan siapa nama seseorang yang tidur di bangsal tersebut untuk memastikan apakah dia pasien atau penunggu pasien.

1.4. Adanya kekeliruan saat uji pretransfusi (lab error)

Contoh kasus di klinik adalah seharusnya pasien A yang diujikan dengan golongan darah tertentu tetapi pasien B yang diujikan. Semua kesalahan diatas akan memberikan dampak yang sangat fatal dimana pada akhirnya pasien akan mendapatkan komponen darah yang tidak pas sehingga akan menimbulkan reaksi transfusi hemolitik yang sangat berat.

\section{Reaksi Hemolisis Transfusi}


Transfusi merupakan suatau proses pemindahan darah dari donor ke resipien yang paling sederhana yang biasa dilakukan saat urgensi dan dapat menimbulkan berbagai akibat fatal salah satunya adalah reaksi hemolitik. ${ }^{13}$ Reaksi hemolitik akibat transfusi dibagi menjadi dua kelompok yaitu reaksi hemolitik yang disebabkan proses imun(immune mediated hemolysis) yang terdiri dari reaksi hemolitik akut (acute hemolytic transfusion reaction, AHTR) dan reaksi hemolitik lambat (delayed hemolytic transfusion reaction, DHTR) dan nonimun (non-immunemediated hemolysis). ${ }^{10}$ Reaksi hemolitik akut atau AHTR umumnya disebabkan oleh kesalahan dalam identifikasi sampel darah resipien atau dalam pencocokan sampel darah resipien dan donor (crossmaatch). Proses hemolitik terjadi di dalam pembuluh darah (intravaskular), yaitu sebagai reaksi hipersensitivitas tipe II. Plasma donor yang mengandung eritrosit dapat merupakan antigen (major incompatability) yang berinteraksi dengan antibodi pada resipien yang berupa imunoglubulin $\mathrm{M}(\operatorname{IgM})$ anti-A, anti-B, atau terkadang antirhesus. Pada reaksi hemolitik lambat atau DHTR diawali dengan reaksi antigen berupa eritrosit donor dan respons antibodi yang terjadi di intravaskuler dan berlanjut ke ekstravaskuler. Plasma donor yang mengandung eritrosit berinteraksi dengan IgG dan atau C3b pada resipien. Selanjutnya eritrosit yang telah diikat IgG dan C3b akan dihancurkan oleh makrofag di hati. Jika eritrosit donor diikat oleh antibodi (IgG1atau IgG3) tanpa melibatkan komplemen, maka ikatan antigen-antibodi tersebut akan dibawa oleh sirkulasi darah dan dihancurkan di limpa. ${ }^{14}$

\section{Reaksi Imunitas Antigen dan Antibodi}

Sistem penggolongan darah secara $\mathrm{ABO}$ merupakan system penggolongan terpenting karena menyebabkan beberapa reaksi hemolytic saat transfusi darah serta dapat menyebabkan hemolytic disease of the newborn. Sistem penggolongan ABO merupakan satu-satunya yang memiliki antigen dan antibodi sekaligus. Setiap individu mempunyai antibodi (isohemagglutinins) dalam plasma darahnya dan antigen pada sel darah merahnya (RBCs). ${ }^{15}$

Golongan darah A memiliki antigen A dan antibodi anti-B, golongan darah B memiliki antigen $\mathrm{B}$ dan antibodi anti-A. Golongan darah $\mathrm{AB}$ memiliki antigen $\mathrm{A}$ dan antigen $\mathrm{B}$ tetapi tidak memiliki antibodi pada serumnya. Golongan darah $\mathrm{O}$ tidah memiliki antigen pada permukaan eritrositnya tapi memiliki antibodies anti-A dan anyibodi anti-B. ${ }^{10}$ Pengecekan golongan darah berfungsi untuk mencegah reaksi transfusi yang dapat menyebabkan inkompabilitas ABO antara pasien dan pendonor. Inkompabilitas ABO dapet disebabkan karena interaksi antara antigen dan antibodi yang menimbulkan aglutinasi. 
Aglutinasi berapa perlekatan antara antigen yang terdapat pada permukaan RBCs dan antibodi pada plasma sehingga menyebabkan suatu anyaman yang menyebabkan sel-sel darah terjerat dan mengelompok. Aglutinasi ini terjadi melalui 2 tahap yaitu perlekatan antigen dan antibodi saat pertama bertemu. Pada tahap ini aglutinasi belum terjadi, tetapi hanya menyelubungi sel. Tahap kedua berupa terbentuknya anyaman menimbulkan gumpalan (aglutinasi).

Antibodi yang berperan dalam reaksi antigen dan antibodi ini adalah $\operatorname{IgM}$ dan $\operatorname{IgG}$. IgM ukuranya lebih besar dan dapat mengaglutinasi sel-sel secara langsung. Sedangkan IgG ukurannya lebih kecil dan tidak dapat secara langsung mengaglutinasi sel-sel tetapi dapat menyelubungi atau mensensitisasi sel-seldarah merah. Berdasarkan stadiumnya, aglutinasi yang merupakan reaksi imunitas antigen antibodi:

1. Sensitasi. Perlekatan antibodi pada RBCs secara fisik. Sebelum terjadi aglutinasi antibodi akan melakukan perlekatan dengan antigen sehingga terbentuk kompleks antigen antibodi. Hal ini akan tampak seperti RBCs dielubungi oleh antibodi.

2. Aglutinasi. Pada stadium ini, setelah terjadi sensitasi, akan terbentuk jembatanjembatan yang antara sel-sel yang telah melekat sehingga terjadi aglutinasi. ${ }^{9}$

\section{Diagnosis Inkompatibilitas ABO}

Inkompatibilitas $\mathrm{ABO}$ dapat terdiagnosa apabila saat transfusi darah pasien mengindikasikan adanya reaksi-reaksi seperti yang telah dijelaskan sebelumnya. Pemeriksaan darah lengkap (DL) dan urin lengkap (UL) sangat dianjurkan untuk memastikan adanya sel darah merah yang lisis atau hemoglobin pada urin sebagai akibat hancurnya sel darah merah.

\subsection{Pemeriksaan Darah Lengkap}

Demi menegakkan diagnosa dari terjadinya hemolisis intravascular maka perlu dilakukan pemeriksaan DL. Dianjurkan untuk melakukan anamensa terlebih dahulu untuk menegakkan penyebab dan tingkat keperahan dari hemolisis intravaskular. Anamnesa yang dianjurkan seperti

riwayat anemia pada keluarga, riwayat penyakit terakhir atau kondisi medis tertentu, konsumsi obat-obatan, paparan zat kimia, dan penggunaan artificial heart valve atau alat medis lainnya yang kemungkinan merusak sel darah merah. Setelah anamnesa, kemudian pemeriksaan fisik dilakukan untuk melihat tanda dan gejala hemolisis intravaskular.

Tanda fisik yang kemungkinan muncul seperti jaundice (kekuningan pada kulit dan mata), tachycardia atau arrhythmia, tachypnea atau pernafasan yang tidak teratur, pembesaran organ spleen, dan pendarahan dalam (internal bleeding). Pemeriksaan DL 
kemudian dilakukan untuk memeriksa kadar hemoglobin, hematocrit, sel darah merah, sel darah putih, dan platelet dalam darah. Hasil yang abnormal menunjukkan kemungkinan hemolisis, kelainan darah, atau infeksi. Namun perlu diperhatikan bahwa nilai normal dari komponen darah tersebut bervariasi antara individu yang berbeda ras atau etnik. Pemeriksaan DL juga dilakukan untuk melihat Mean Corpuscular Volume (MCV) atau rata-rata ukuran sel darah merah sebagai data penunjang dalam menentukan kemungkinan penyebab anemia. ${ }^{16}$

\subsection{Pemeriksaan Urin Lengkap (UL)}

Pemeriksaan UL dilakukan sebagai pemeriksaan penunjang dengan menemukan hemoglobin pada sampel urin. Apabila terjadi lisis sel darah merah intravaskular, hemoglobin yang berada di plasma darah akan diikat oleh haptoglobin, hemopexin, dan albumin. Namun apabila kapasitas hemoglobin melebihi protein pengikatnya, maka hemoglobin bebas akan diabsorbsi di tubulus renalis. Apabila kapasitas hemoglobin bebas melebihi yang dapat diabsorbsi, maka hemoglobin dapat ditemukan dalam urine. Hal ini mengindikasikan bahwa telah terjadi lisis sel darah merah yang sangat banyak sebagai akibat dari inkompatibilitas ABO pada sel darah merah. ${ }^{17}$

\section{Penatalaksanaan dari Inkompatibilitas}

5.1. Penatalaksanaan Umum

Secara umum, penatalaksanaan yang perlu dilakukan pada kasus inkompatibilitas ABO adalah pemberian obat yang bersifat meredakan reaksi alergi, seperti antihistamin; obat yang menurunkn reaksi inflamasi seperti steroid; pemberian cairan fisiologis secara intravena; serta pemberian obat yang menaikkan tekanan darah seperti epinefrin apabila penurunan tekanan darah terjadi secara drastis. ${ }^{17,18}$

\subsubsection{Penatalaksanaan Inkompatibilitas ABO pada Transfusi}

Pada kasus inkompatibilitas ABO yang terjadi pada transfusi darah, hal pertama yang perlu dilakukan tenaga kesehatan adalah menghentikan transfusi secepatnya lalu memberikan infus cairan salin yang bertujuan menghindarkan penderita mengalami kegagalan ginjal, pembekuan darah berkepanjangan, dan penurunan tekanan darah yang drastic. Selain itu, perlu juga dilakukan pemberian oksigen yang cukup untuk penderita dan juga obat yang dapat menstimulasi pengeluaran urine. Apabila penderita memiliki kecenderungan untuk mengalami pembekuan darah yang menyebar, sebaiknya mendapatkan transfusi plasma atau trombosit. ${ }^{20}$

\subsubsection{Penatalaksanaan Inkompatibilitas ABO pada Neonatus}


Penatalaksanaan kasus inkompatibilitas ABO pada neonatus umunya lebih berfokus pada penanganan hiperbilirubinemia. Pada beberapa penelitian, IVIG (Intravenous Immunoglobulin) dinyatakan sangat efektif ketika diberikan di awal terapi. Namun, ada pula beberapa penelitian lain yang menyatakan bahwa terapi dengan IVIG tidak memberikan dampak yang signifikan, akan tetapi cocok dilakukan apabila kadar bilirubin serum sudah mencapai ambang transfusi tukar terlepas dari fototerapi. Selain itu, porfirin tin (Sn), sebuah inhibitor heme oksigenase yang poten, telah dinyatakan dapat menurunkan produksi dari bilirubin dan mengurangi kebutuhan untuk melakukan transfusi tukar. ${ }^{20}$ Fokus utama ditekankan pada manajemen dari hiperbilirubinemia. Pada inkompatibilitas ABO yang terjadi pada neonates, penatalaksanaan secara umum dibagi menjadi 2 yakni penatalaksanaan secara farmakologi dan non farmakologi.

\section{Farmakologi}

Penatalaksanaan farmakologi pertama adalah pemberian obat pengikat bilirubin. Pemberian oral arang aktif atau agar menurunkan secara bermakna kadar bilirubin rata-rata selama 5 hari pertama setelah lahir pada bayi sehat, tetapi potensi terapeutik modalitas ini belum diteliti secara ekstensif. Penatalaksanaan farmakologis yang kedua yaitu blokade perubahan heme menjadi bilirubin. Modalitas terapi ini ialah dengan mencegah pembentukan bilirubin dengan menghambat heme oksigenase yang akan menghambat penguraian heme menjadi bilirubin. Umumnya, metaloporfirin sintetik seperti protoporfirin timah sering digunakan karena yang terbukti dapat menghambat heme oksigenase, mengurangi kadar bilirubin serum, dan meningkatkan ekskresi heme yang tidak dimetabolisme melalui empedu. Karena potensi toksisitas dari modalitas terapi ini belum diketahui secara pasti, maka jenis obat ini belumditerapkan secara klinis pada anak. Selain protoporfirin timah, tersedia juga protoporfirin seng atau mesoporfirin.

\section{Non Farmakologi}

Penatalaksanaan non farmakologi yang paling lazim dilakukan adalah fototerapi. Fototerapi saat ini masih menjadi modalitas terapeutik pada bayi dengan ikterus dan merupakan terapi primer pada neonatus dengan hiperbilirubinemia tidak terkonjugasi. Bilirubin yang bersifat fotolabil, akan mengalami beberapa fotoreaksi apabila terpajan ke sinar dalam rentang cahaya tampak, terutama sinar biru (panjang gelombang $420 \mathrm{~nm}-470$ $\mathrm{nm}$ ) dan hal ini akan menyebabkan fotoisomerasi bilirubin. Turunan bilirubin yang dibentuk 
oleh sinar bersifat polar oleh karena itu akan larut dalam air danakan lebih mudah 'diekskresikan melalui urine. Bilirubin dalam jumlah yang sangat kecil juga akan dipecah oleh oksigen yang sangat reaktif secara irreversible yang diaktifkan oleh sinar. Produk fotooksidasi ini juga akan ikut diekskresikan melalui urine danempedu. Fototerapi kurang efektif diterapkan pada bayi dengan penyakit hemolitik, tetapi mungkin dapat berguna untuk mengurangi laju akumulasi pigmen setelah melakukan transfusi tukar. Efektivitas terapi sinar terutama dipengaruhi oleh seberapa luas bagian kulit bayi yang terpapar oleh sinar dikarenakan proses isomerisasi terbanyak terjadi pada bagian perifer yaitu di kulit atau kapiler jaringan subkutan, jumlah energi cahaya yang menyinari kulit bayi, pengubahan posisi bayi secara berkala, jarak antara sumber cahaya dengan bayi diatur agar bayi mendapatkan energi cahaya yang optimal (tidak boleh melebihi $50 \mathrm{~cm}$ dan kurang dari $10 \mathrm{~cm}$ ). Energi cahaya yang optimal bisa didapatkan dari lampu neon 20 Watt yang ada di pasaran dengan panjang gelombang sinar antara 350-470 $\mathrm{nm}$. Selain penggunaan lampu neon, dibutuhkan pula pleksiglas untuk memblokade sinar ultraviolet, dan filter biru untuk memperbesar energi cahaya yang sampai pada bayi. Beberapa hal yang perlu diperhatikan selama berlangsung terapi sinar ini ialah:

a) Diusahakan seluruh permukaan tubuh bayi terpapar sinar, jad pakaian bayi dilepas.

b) Kedua mata dan gonad ditutup dengan penutup yang memantulkan cahayauntuk melingungi sel-sel retina dan mencegah gangguan maturasi seksual.

c) Bayi diletakkkan 8 inci di bawah sinar lampu, jarak ini ialah jarak terbaik untuk mendapat energi cahaya yang optimal.

d) Posisi bayi diubah setiap 18 jam agar seluruh badan terpapar sinar.

e) Pengukuran suhu bayi setiap 4-6 jam/kali.

f) Kadar bilirubin diukur setiap 8 jam atau sekurang-kurangnya sekali dalam 24 jam.

g) Perhatikan hidrasi bayi, bila perlu tingkatkan konsumsi cairan bayi.

h) Lama terapi sinar dicatat.

Bila terapi sinar tidak menunjukkan ada penurunan kadar bilirubin serum yang berarti, dapat diduga kemungkinan lampu yang tidak efektif atau adanya komplikasi pada bayi berupa dehidrasi, hipoksia, infeksi atau gangguan metabolisme yang harus diperbaiki. Beberapa efek samping yang dapat terjadi pada bayi dengan terapi sinar, antara lain peningkatan insensible water loss pada bayi sehingga perlu diberikan pemberian cairan yang lebih diperhatikan, frekuensi defekasi bayi meningkat akibat peningkatan peristatltik usus, dapat terjadi diskolorasi gelap di kulit (bronze baby) akibat penimbunan fotoderivatif bilirubin yang 
kecoklatan dalam darah, kerusakan retina yang dilaporkan pada hewan percobaan bersamaan dengan meningkatnya risiko retinopati pada bayi oleh karena itu perlindungan mata bayi sangatlah penting, hipokalsemia yang lebih umum nampak pada bayi prematur, kenaikan suhu bayi yang berlebihan. Walau begitu, terapi sinar masih dianggap sebagai terapi yang sangat aman dan tidak memiliki efek samping serius yang berkelanjutan, efek samping akan hilang ketika terapi dihentikan segera. ${ }^{20}$

Selain fototerapi, ada pula penatalaksanaan non farmakologi lainnya, yaitu transfusi tukar. Pada umumnya, transfusi tukar dilakukan dengan indikasi sebagai berikut:

a) Pada semua keadaan dengan kadar bilirubin indirek $<20 \mathrm{mg} \%$.

b) Kenaikan kadar bilirubin indirek yang cepat, yaitu 0,3-1 mg\%/jam.

c) Anemia yang berat pada neonatus dengan gejala gagal jantung.

d) Bayi dengan kadar hemoglobin talipusat $<14 \mathrm{mg} \%$ dan uji Coombs direk positif.

Transfusi tukar dilakukan dengan indikasi untuk menghindari efek toksisitas bilirubin ketika semua modalitas terapeutik telah gagal atau tidak mencukupi. Sebagai tambahan, prosedur ini dilakukan dengan bayi yang memiliki indikasi eritroblastosis dengan anemia hebat, hidrops, atau bahkan keduanya bahkan ketika tidak adanya kadar bilirubin serum yang tinggi. Transfusi tukar terutama direkomendasikan ketika terapi sinar tidak berhasil dan ketika bayi mengalami ikterus akibat $\mathrm{Rh}$ isoimunisasi dan inkompatibilitas $\mathrm{ABO}$ sehingga jenis ikterusnya dapat dikatakan sebagai ikterus hemolitik dan memiliki risiko neurotoksisitas yang lebih tinggi dibanding ikterus non-hemolitik. Prosedur ini dilakukan dengan mengurangi kadar bilirubin hingga hampir 50\% dan juga menghilangkan sekitar $80 \%$ sel darah merah abnormal yang telah tersensitisasi serta melawan antibodi agar proses hemolisis tidak terjadi. Prosedur ini bersifat invasif dan bukan prosedur yang bebas risiko, karena prosedur ini memiliki risiko mortalitas sebesar $1-5 \%$, dapat pula berkomplikasi menjadi necrotizing enterocolitis (NEC), infeksi, gangguan elektrolit, ataupun trombositopenia sehingga prosedur ini harus dilakukan secara hati-hati.

Sebelum dilakukan transfusi dapat diberikan albumin $1,0 \mathrm{~g} / \mathrm{kg}$ untuk mempercepat keluarnya bilirubin ekstravaskuler ke vaskuler sehingga bilirubin yang diikatnya akan lebih mudah dikeluarkan dengan transfusi tukar, lalu kemudian diberikan IVIG 0,5-1 g/kg untuk kasus hemolisis yang diperantarai oleh antibodi. ${ }^{19}$

Berdasarkan pemaparan di atas, penatalaksanaan inkompatibilitas ABO pada neonatus secara singkat disajikan dalam tabel berikut. 


\begin{tabular}{|c|c|c|c|c|}
\hline Bilirubin (mg\%) & $<24$ jam & 24-48 jam & 49-72 jam & >72 jam \\
\hline$<5$ & \multicolumn{3}{|c|}{ Pemberian makanan yang dini } & \\
\hline $5-9$ & $\begin{array}{r}\text { Terapi sinar } \\
\text { bila hemolisis }\end{array}$ & Phenobarbital + Kalori cukup & \\
\hline $10-14$ & $\begin{array}{r}\text { Terapi sinar } \\
\text { bila hemolisis }\end{array}$ & Terapi sinar & & \\
\hline $15-19$ & Transfusi tukar & Tranfusi tukar bila hemolisis & terapi + & + \\
\hline$>20$ & & Transfusi Tukar & \\
\hline
\end{tabular}

Tabel 1. Pedoman pengelolaan Ikterus menurut waktu timbul dan kadar bilirubin

\section{Prognosis Dari Inkompatibilitas ABO System}

Inkompatibilitas $\mathrm{ABO}$ yang terjadi pada seseorang atau janin dapat mengakibat menyebabkan komplikasi yang serius atau bahkan kematian. Pengukuran titer antibody dengan tes Coombs sangat di perlukan. Dimana tes tersebut ada dua yaitu indirect dan direct, yang mana indirect Coombs di lakukan pada serum darah dan dilakukan sebelum tranfusi darah atau pada janin, sedangkan direct dilakukan pada eritrosit dan dilakukan pada bayi baru lahir. Apabila pada pengukuran titer antibodi dengan tes coombs indirect menunjukkan hasil positive maka itu menunjukkan ketidak cocokan atau inkompaibilitas golongan darah dan menunjukkan adanya antibodi terhadap darah $\mathrm{Rh}+$ pada wanita $\mathrm{Rh}$ - yang tengah hamil. tetapi untuk wanita $\mathrm{Rh}$ yang tengah hamil, apabila titer coombs kurang dari 1:16 maka pasien dapat melanjutkan kehamilannya, namun jika titer lebih dari 1:16 pada kehamilan yang kedua atau ketiga, maka dianjurkan perawatan intensif perinatal selama kehamilan , persalinan , dan masa neonatal. ${ }^{20}$

\section{KESIMPULAN}

Sistem pegolongan darah $\mathrm{ABO}$ merupakan sistem golongan darah yang terpenting dalam transfusi. Sistem penggolongan darah ini adalah yang paling imunogenik dari semua antigen golongan darah. Ketidakcocokan atau inkompatibilitas dalam konteks golongan darah ini disebabkan oleh pengikatan antibodi plasma dengan antigen sel darah merah, sehingga menyebabkan reaksi. Dalam tes laboratorium reaksi ini adalah yang paling umumnya divisualisasikan dengan aglutinasi dari sel-sel darah merah. Di tubuh, reaksi antigen-antibodi dapat terjadi sebagai konsekuensi yang merugikan dari transfusi darah atau kehamilan, mengakibatkan kerusakan sel darah merah dipercepat. Oleh karena itu penting untuk 
mendeteksi ketidaksesuaian antara plasma pasien dan sel darah merah dari donor darah potensial sebelum transfusi, untuk menghindari reaksi transfusi.

Ada berbagai faktor yang menyebabkan terjadinya inkompatibilitas pada sistem ABO. Yang pertama karena adanya reaksi hemolitik fatal karena ABO transfus darah yang tidak kompatibel yang disebabkan karena adanya kesalahan identifikasi (nursing error), Label sample darah tertukar (phlebotomist error), Adanya kesalahan saat mengambil sample (phlebotomist error), Adanya kekeliruan saat uji pretransfusi (lab error). Selain itu juga dapat terjadi karena adanya reaksi hemolitik akibat transfusi dan adanya reaksi imunitas antigen antiodi.

Provinsi Aceh yang jumlah penduduknya 5096248 jiwa dan Kota Banda Aceh sebagai pusat pemerintahan dengan jumlah penduduk 254,904 jiwa, merupakan barometer pengukuran kesehatan di provinsi Aceh. Penelitian dilakukan di Unit Transfusi Darah UTD PMI Kota Banda Aceh dengan melihat kasus inkompatibilitas selama 2018. Pada hasil penelitian menunjukkan presentase kasus inkopatibilitas ABO sebesar 0,5\%. Dari kasus ini diharapkan adanya pengetahuan yang baik dari ibu hamil terkait resiko yang akan dialami dari proses hingga persalinan berlangsung sehingga komplikasi yang muncul dapat dihindari karena faktor ketidak tahuan, dan bagi tenaga medis diharapkan dapat memberikan tidakan cepat pada kasus inkompatibilitas ABO yang dapat menyebabkan HDN (hemolytic disease of the newborn). Deteksi dini sangat penting guna mencegah komplikasi yang dapat muncul nantinya, inkompatibilitas $\mathrm{ABO}$ dapat terdiagnosa apabila saat transfusi darah pasien mengindikasikan adanya reaksi-reaksi seperti yang telah dijelaskan sebelumnya. Pemeriksaan darah lengkap (DL) dan urin lengkap (UL) sangat dianjurkan untuk memastikan adanya sel darah merah yang lisis atau hemoglobin pada urin sebagai akibat hancurnya sel darah merah. Inkompatibilitas ABO yang terjadi pada seseorang atau janin dapat menyebabkan komplikasi yang serius atau bahkan kematian. Pengukuran titer antibody dengan tes Coombs sangat di perlukan.

\section{REFERENSI}

1. Kemenkes RI. Profil Kesehatan Indonesia. In: Kesehatan, editor. Jakarta: Kemenkes RI; 2014.

2. American Academy of pediatrics, Subcommite on Hyperbilirubinemia. 2004. Management of Hyperbilirubinemia in the Newborn Infant 35 or more Weeks of Gestasion. Jurnal Pediatrics, 114: 297-306

3. Schwartz, M., Wiliam. (2005). Pedoman Klinis Pediatri. Jakarta: EGC 
4. ABO Grouping - Gonsorcik, Victoria [Internet]. Medscape.com.2013 [cited 10arch 2017]. Available from: http://emedicine.medscape.com/article/1731198-overview.

5. Etika, R., Agus, H., Fatimah, L., Sylvianti, M. D. 2006. Hyperbilirubinemia in neonatus. Surabaya : Fakultas Kedokteran Universitas Airlangga.

6. Wiknjosastro, Hanifa. Ilmu Kebidanan. Jakarta: Yayasan Bina Pustaka Sarwono Prawirohardjo; 2009

7. Saifudin AB. Ilmu Kebidanan. 4th ed. Jakarta: P.T. Bina Pustaka Sarwono Prawirohardjo; 2009

8. Rekam Medis Nirmala Suri. (2010). Sukoharjo

9. Permenkes No 91 tahun 2015

10. Strobel E. Hemolytic transfusion reaction. Transfus Med Hemother. 2008;35:346-53

11. AABB. Technical manual. in: Brecher ME, editor Pretransfusion testing: Res cell antigen-antibody reaction and their detection . $15^{\text {th }}$ ed; United States : AABB. 2005; Chapter 8;175-201.

12. Joyce Poole, International Blood, and Group Reference, 'Blood Group Incompatibility', 2010 .

13. Fasano R, Luban NL. Blood component therapy. Pediatr Clin N Am. 2008;55:421-55.

14. Giroux AG.(1997) Erythroblastosis fetalis. In: Fanaroff AA, Martin RJ. Neonatal perinatal medicine diseases of the fetus and infant. 6th ed. St. Louis: Mosby Year Book.

15. Adriansyah, Rizky dkk. Reaksi Hemolitik Akibat Transfusi. Maj Kedokt Indon, Volum: 59, Nomor: 8, Agustus 2009.

16. Strobel E. Hemolytic Transfusion Reactions. Transfusion Medicine and Hemotherapy. 2008;35(5):346-353.

17. Todd G. ABO incompatibility. 2015.

18. David C. Times health guide: ABO incompatibility. 2012

19. Mathyas T. Penyakit hemolitik et causa inkompatibilitas ABO. 2014

20. Kliegman RM, Stanton BF, Schor NF, et al. Nelson textbook of pediatrics.19th ed.Philadelphia: Elsevier Saunders; 2011.p.619. 